Article

\title{
Intangible Assets and Labor Productivity Growth
}

\author{
Carolina Hintzmann ${ }^{1, *}$, , Josep Lladós-Masllorens ${ }^{1}$ (i) and Raul Ramos $2, * \mathbb{C}$ \\ 1 Economic \& Business Department, Universitat Oberta de Catalunya (UOC), 08035 Barcelona, Spain; \\ jlladosm@uoc.edu \\ 2 AQR-IREA Research Group, Department of Econometrics, Statistics and Applied Economics, \\ University of Barcelona, 08034 Barcelona, Spain \\ * Correspondence: chintzmann@uoc.edu (C.H.); rramos@ub.edu (R.R.)
}

Citation: Hintzmann, Carolina, Josep Lladós-Masllorens, and Raul Ramos. 2021. Intangible Assets and Labor Productivity Growth.

Economies 9: 82. https://doi.org/ 10.3390/economies 9020082

Academic Editor: Ralf Fendel

Received: 23 February 2021

Accepted: 14 May 2021

Published: 24 May 2021

Publisher's Note: MDPI stays neutral with regard to jurisdictional claims in published maps and institutional affiliations.

Copyright: (C) 2021 by the authors. Licensee MDPI, Basel, Switzerland. This article is an open access article distributed under the terms and conditions of the Creative Commons Attribution (CC BY) license (https:// creativecommons.org/licenses/by/ $4.0 /)$.

\begin{abstract}
We examine the contribution to labor productivity growth in the manufacturing sector of investment in different intangible asset categories-computerized information, innovative property, and economic competencies-for a set of 18 European countries between 1995 and 2017, as well as whether this contribution varies between different groups of countries. The motivation is to go a step further and identify which single or combination of intangible assets are relevant. The main findings can be summarized as follows. Firstly, all the three different categories of intangible assets contribute to labor productivity growth. In particular, intangible assets related to economic competences together with innovative property assets have been identified as the main drivers; specifically, advertising and marketing, organizational capital, research and development (R\&D) investment, and design. Secondly, splitting the sample of European Union (EU) member states into three groups-northern, central and southern Europe-allows for the identification of a significant differentiated behavior between and within groups, in terms of the effects of investment in intangible assets on labor productivity growth. We conclude that measures promoting investment in intangibles at EU level should be accompanied by specific measures focusing on each country's needs, for the purpose of promoting labor productivity growth. The obtained evidence suggests that the solution for the innovation deficit of some European economies consist not only of raising R\&D expenditure, but also exploiting complementarities between different types of assets.
\end{abstract}

Keywords: intangible capital; labor productivity; manufacturing

\section{Introduction}

Since 1995, the rate of labor productivity growth in Europe has been declining throughout almost the whole considered period, with the exception of two short positive time spans coinciding with the upswing of the business cycle at the end of the 1990s and around 2006-2007. Finally, during the Great Recession of 2008-2009, the European Union (EU) saw a decline in labor productivity parallel to the contraction of the economy. Although some EU members are showing good performance in terms of recovery, others are displaying difficulties (Corrado et al. 2016a, 2016b, 2018). The crisis that started in 2008 has changed the perceptions of the role of the manufacturing industry. It brought the benefits of a strong and stable manufacturing base back to the center of the scene.

As a consequence, many authors have tried to find explanations to the declining trend of labor productivity growth over the last two decades (Kim et al. 2021; Roth 2020; McGrattan 2020; Piekkola 2020; Inklaar et al. 2019; Pyka et al. 2019; Park and Choi 2019; Danileviciene and Lace 2017; Corrado et al. 2005, 2006, 2009, 2017a, 2017b, 2018; Bounfour and Miyagawa 2015; Van Ark and Jäger 2017; Van Ark 2016; Van Ark and O’Mahony 2016; Van Ark et al. 2009; Marrano and Haskel 2006; van Rooijen-Horsten et al. 2008; Fukao et al. 2009; Hao et al. 2009; Marrano et al. 2009; Mc Morrow et al. 2010; Edquist 2011; Strobel 2012; Mas and Stehrer 2012; Timmer et al. 2010; Timmer et al. 2011). Their results analyzing the reasons for the slow labor productivity growth in EU member states suggest that it 
might be explained by the differences in the accumulation of intangible assets that play a complementary role to information and communication technologies (ICT) capital.

The nature of the impact of the inclusion of intangible capital in the growth accounting model is similar across the countries for which the estimates are available. It determines an increase in labor productivity growth and in the contribution of capital deepening, and a decrease in total factor productivity (TFP) growth (Niebel et al. 2017; Corrado et al. 2018). But intangible expenditure is currently treated as current expense in the national accounts rather than as an investment. This determines an understatement of investment in the economy and an incomplete picture of the main sources of growth.

In this context, it is worth mentioning that several authors have grouped the countries attaining different criteria, such as geographical, size of the economies considered or the strengths or weakness of their industry. For example, as said above, Piekkola (2017) defines country groups as northern, central and southern Europe, while Novotna and Volek (2018) classify countries as "old" and "new" EU member states. Van Ark and Jäger (2017) group the countries into large (France, Germany, Italy, Spain and United Kingdom) and small economies (Austria, Belgium, Czechia, Denmark, Finland, The Netherlands and Sweden) and within each group they differentiate those countries that have a strong manufacturing sector and those that do not. Peiró-Palomino (2016) analyses convergence in intangible investment by region, and groups the countries considered into Mediterranean, eastern and central Europe. Furthermore, Corrado et al. (2013) classify the sample into Scandinavian (Denmark, Finland, Sweden), Anglo-Saxon (Ireland, United Kingdom), continental (Austria, Belgium, France, Germany, Luxemburg, The Netherlands) and Mediterranean (Greece, Italy, Portugal, Spain), and Pianta (2013) differentiates countries between "center" and "periphery", in terms of whether they have a strong industry or not.

The aim of this research is to explore the contribution to labor productivity growth of investment in different single intangible asset categories-computerized information, innovative property, and economic competencies-in manufacturing industry for a set of 18 European countries (Austria, Czechia, Denmark, Estonia, Finland, France, Germany, Latvia, Lithuania, Luxembourg, Italy, The Netherlands, Romania, Slovakia, Slovenia, Spain, Sweden, and United Kingdom) between 1995 and 2017. In the context of the knowledge economy, and with the aim of going a step further against this background, it is interesting to investigate the role of intangible investment attaining the country-specific characteristics.

Thus, by grouping our sample of countries into northern, central and southern Europe following Piekkola (2017), we want to explore to what extent investment in intangible assets on labor productivity growth depends on country-specific characteristics, confirming the existence of heterogeneous effects between and within them.

The results should help us to identify which single or combination of intangible asset types are the main drivers of labor productivity growth, in order to define and establish adequate common, as well as country-specific, industrial policy measures to promote a better economic performance.

The main contribution of our analysis is not to demonstrate if investment in intangibles contributes to labor productivity growth and which type is a major driver, as McGrattan (2020); Piekkola (2020); Roth (2020); Park and Choi (2019); Muntean (2014); Roth and Thum (2013); Ilmakunnas and Piekkola (2014); and Corrado et al. (2014b, 2017a, 2017b, 2018), among others, have already shown, but, in contrast to other analyses (Roth 2020; Corrado et al. 2018; Niebel et al. 2017), we want to go a step further and identify which of them might be complementary, as well as to find out whether there are heterogeneous effects between the chosen groups of countries. Considering the potential differences of the impact of intangible investment between the considered countries, it may help to define strategies focusing on the specific characteristics and needs to improve labor productivity performance for industry in our sample of countries. In contrast to many other studies (Dal Borgo et al. 2013; Edquist 2011; Hao et al. 2009) that examine the business or the market sector, we focus our analysis on manufacturing industry instead of a broader set of economic sectors, as it is considered a key driver of labor productivity growth 
(Coad and Vezzani 2017; European Commission 2009, 2012, 2013a). The fact that some EU countries with a large and stable manufacturing base have better overcome the crisis and also recovered earlier has redeemed the reputation of the manufacturing industry. To have a dynamic manufacturing sector is considered again a prerequisite for an innovative and fast-growing economy (Aiginger and Rodrik 2020).

All this explains the resurgence and renewed interest in industrial policy and in how to design and implement targeted, but also homogeneous policy measures (Coad and Vezzani 2017; European Commission 2012, 2013a, 2013b; Dhéret 2014; Pianta 2013; O'Sullivan et al. 2013). Having barely recovered from the last crisis of 2007-2008, the economy is facing a new crisis caused by the outbreak of the COVID-19 pandemic. EU industries are suffering this harmful thread, as many have had to shut down or reduce their production as well as reduce their labor force, while being under severe financial pressure. They have to find new ways to survive within a new background due to restrictive measures.

In recent years, investment has shifted from tangible to intangible capital, but depending on the countries, the contribution of intangible investment to labor productivity growth clearly differs from that of tangibles (Roth 2020; Corrado et al. 2017a, 2018; Niebel et al. 2017; Falk 2013). Therefore, different intangible investment strategies might lead to differentiated contributions to labor productivity growth, which results in some countries displaying a better performance than others. This fact explains the interest in grouping our sample of countries.

Taking all this into account, the hypotheses that we consider in this research are the following:

Hypothesis 1 (H1). Investment in intangible assets contributes to the growth of labor productivity in manufacturing in European economies.

Hypothesis 1a (H1a). Computerized information, innovative property and economic competences make a different contribution to the growth of labor productivity in manufacturing.

Hypothesis $\mathbf{1 b} \mathbf{( H 1 b ) . ~ T h e ~ c o m b i n a t i o n ~ o f ~ d i f f e r e n t ~ t y p o l o g i e s ~ o f ~ i n t a n g i b l e ~ a s s e t s ~ a c c e l e r a t e s ~ t h e ~}$ rate of growth of labor productivity in manufacturing.

Hypothesis 2 (H2). The influence of intangible assets investment on labor productivity in manufacturing depends on country-specific characteristics.

Hypothesis 2a (H2a). The contribution of RED investment to explain differences in labor productivity growth is higher among northern European economies.

Hypothesis $\mathbf{2 b} \mathbf{b} \mathbf{H} \mathbf{2 b})$. The contribution of intangible assets investment to explain differences in labor productivity growth is negligible in central European economies.

Hypothesis 2c $(\mathbf{H} 2 \mathrm{c})$. The contribution of intangible assets investment to explain differences in labor productivity growth is higher among southern European economies.

The investigation also aims to identify which of the different intangible assets are the most decisive in triggering a higher labor productivity in European manufacturing. Consequently, it aims to provide some orientations for industrial policy. The research is focused on a wide and unexplored time period, and it takes into account the distinct influence of intangible assets according to the different sources of knowledge and the geographical grouping of countries. These are the main contributions of our research to the previous literature.

The rest of the article is organized as follows: Section 2 briefly summarizes some of the literature background on intangibles and productivity growth. Section 3 presents a description of the data and methodology. Section 4 shows the results, Section 5 discusses and, finally, Section 6 concludes, indicating the main implications. 


\section{Background Literature}

There is an extensive literature on intangible investments, addressing issues such as their measurement, the convenience of capitalizing on and including them in the national accounting system, as well as their contribution to labor productivity growth (Kim et al. 2021; Roth 2020; Kaus et al. 2020; Bisztray et al. 2020; Piekkola 2017; Corrado et al. 2005, 2017a, 2018; Niebel et al. 2017; Marrano et al. 2009; Chun et al. 2012; Goodridge et al. 2013; Baldwin et al. 2012; Miyagawa and Hisa 2013). As Roth (2020) says, analysis in this field has been undertaken focusing on different aspects, such as individual or groups of countries, industry, firms, on complementary investments, among others.

Research on this issue undertaken by Corrado et al. $(2005,2006,2009,2013,2017$ a, 2018) marks the beginning of a number of studies measuring intangible investment and showing the relevance of intangible capital for labor productivity growth. Departing from Nakamura's $(1999,2001)$ analysis, they developed expenditure-based measures of a large range on intangibles for the United States (US). The contribution of labor composition and physical, or tangible, capital deepening to labor productivity has been well researched. In contrast, until recently, intangible assets were not considered as contributors to labor productivity growth. Similar studies have been conducted in Canada, (Muntean 2014), Japan (Fukao et al. 2009), Australia (Barnes and McClure 2009) and Europe (Corrado et al. 2013; Goodridge et al. 2013; Roth and Thum 2013; Jona Lasinio et al. 2011; Jalava et al. 2007).

Until recently, spending on intangible assets was counted as an intermediate expense in the systems of national accounts, rather than as investment in intangible capital. Corrado et al. (2009) indicate that specific features of some intangible assets, such as non-rivalry and the lack of verifiability, visibility and appropriability of returns, explain the fact that the majority of intangible assets are disqualified as capital. These authors, however, argue that these distinct features do not make intangible assets an intermediate good (Muntean 2014).

Corrado et al. (2006) argue that the reason for treating intangibles as capital is that any use of resources that reduces current consumption in order to increase it in the future can be considered as an investment. It has not been so long since computer software started to be treated as capital in the national accounts of many countries, whereas many other intangibles, for example research and development (R\&D), are currently not. Intangible assets are generally defined as assets that provide future benefits, but do not have a physical embodiment, such as software, R\&D, market, and consumer research.

Despite their uniqueness, intangible assets share basic common characteristics with physical capital. As with any other type of capital, intangibles are used in the production of goods and services and provide future benefits. As with investment in physical capital, investment in intangible assets represents foregone current consumption for the benefit of greater future consumption.

Thus, intangible assets should be classified as capital and spending on intangibles should be counted as investment rather than operational or intermediate expenses. Otherwise, the aggregate level of output would remain underestimated. This potentially creates distortions in business investment and resource allocation. In addition, effectiveness of public policy may also be adversely affected if investment and capital in the economy are measured imprecisely. These distortions could ultimately lead to a decline in productivity and economic growth.

As Jona Lasinio et al. (2011) state, there is a large number of studies on intangible investment and its appropriate measurement and contribution to labor productivity growth. The problem is that most of them focus only on some assets (R\&D capital, for example), leaving out other elements such as organizational capital or brand equity. But some authors, such as Sichel (2008), have gone a step further in implementing new approaches to measuring intangibles as financial market valuation, direct expenditure data and other performance measures. 
Taking into account a possible revision of the national accounting framework, Corrado et al. (2005) proposed a broader definition for innovation in order to examine its impact on labor productivity growth. For this purpose, they grouped the various items that constitute the knowledge of the firm into three basic categories: (i) computerized information, (ii) innovative property and (iii) economic competencies.

Computerized information includes knowledge which is embedded in computer programs and computerized databases. Innovative property includes the scientific knowledge embedded in patents, licenses, and general know-how, as well as "the innovative and artistic content in commercial copyrights, licenses and designs" (Corrado et al. 2005, pp. 23-26).

The economic competencies category is defined as "the value of brand names and other knowledge embedded in firm-specific human and structural resources" (Corrado et al. 2005 , p. 28). It includes expenditures on advertising, market research, firm-specific human capital, and organizational capital. These measures try to capture a range of knowledge assets that firms invest in to run their business, which are key to encouraging labor productivity growth. Examples of those are an increase in the selling potential of a product, the development of processes and a productive environment for the actual physical production of a good.

Brynjolfsson et al. $(2002,2017)$ showed the positive relationship between computerized information, here in particular via an interaction effect with organizational capital, on labor productivity growth. Other authors such as Lichtenberg (1993); Coe and Helpman (1995); Park (1995); and Guellec and Potterie (2001) did the same with certain dimensions of innovative property (scientific R\&D), demonstrating its contribution to labor productivity growth.

The single dimensions of economic competencies, namely brand names, firm-specific human capital, and organizational capital are also relevant in stimulating labor productivity growth.

Following Roth and Thum (2013), brand names should positively affect labor productivity growth since an important aspect of today's products is the "image" attached to them. The ownership of a brand that is appealing to customers permits a seller to acquire a higher margin for goods or services that are similar to those offered by competitors. Expenditure on market research comprises, next to expenditure on advertising, an important part of the investment in brand equity (Cañibano et al. 2000).

Another important asset of a firm is firm-specific human capital. Cañibano et al. (2000) stress that a firm with more competent employees is likely to acquire higher profits than competitors whose workers are less skilled. In this regard, Abowd et al. (2005) argue that the value of companies will increase if the quality of their human resources increases.

Organizational capital of a firm is another relevant dimension of economic competencies. In an era where goods become more and more sophisticated and production processes are becoming more complex, the management of the production process that involve highly technological physical capital is a key factor for the firm. Organizational capital is defined by Lev and Radhakrishnan (2005, p. 75) as "an agglomeration of technologies-business practices, processes and designs and incentive and compensation systems-that together enable some firms to consistently and efficiently extract from a given level of physical and human resources a higher value of product than other firms find possible to attain". They (Lev and Radhakrishnan 2003, 2005) considered it the only competitive asset truly owned by a firm, while the others are tradable and thus available for every firm that wants to invest in them.

There is a vast amount of literature showing and examining it for the different types of intangibles and from different points of view. Belhocine (2009) finds that in Canada, if spending on intangible assets is not included in aggregate investment, real gross domestic product (GDP) growth is, on average, underestimated by 0.1 percentage points per year from 1999 to 2001. It is underestimated by about 0.25 percentage points for 2004 (Muntean 2014, p. 23). 
Corrado et al. (2009) indicate that in the US, if investment in intangibles is not included, GDP growth is underestimated by about 0.25 percentage points per year from 1995 to 2002 . Further studies on the contribution of intangibles to labor productivity growth, such as the one undertaken by Van Ark et al. (2009) focusing on the market sector in the US and selected European countries for the 1995-2006, show that intangible capital deepening contributed on average 0.83 percentage points in the US and 0.72 percentage points in the larger European countries (Muntean 2014, p. 23). Dal Borgo et al. (2013) showed that, for the period from 2000 to 2008 , intangible capital deepening accounted for $23 \%$ of growth in market sector value added in the United Kingdom, a larger contribution than computer hardware $(12 \%)$.

Ilmakunnas and Piekkola (2014) demonstrate that investment in organizational capital has a positive influence on labor productivity growth. The results obtained by Yallwe and Buscemi (2014), who discuss the contributions of intellectual assets to labor productivity growth, are also positive.

Data obtained by Corrado et al. (2018, pp. 15-22; 2013, p. 278) show that the rate of tangible investment in the EU15 declined sharply from 2007 to 2009, while the rate of intangible investment remained about flat. In the US, intangible investment fell. Across Europe, there are small differences by region, and intangible investment relative to tangibles held up better in recent years on both continents. Overall, the shift to intangible investment from 1995 to 2009 is a striking trend.

In this context, there are still many issues that have not been tackled yet in the literature. The present research contributes to advances in this topic by considering how the single categories of intangible investment influence labor productivity growth in the manufacturing industry, and which combinations are more appropriate than others. Furthermore, we want to find out whether there are heterogeneous effects of investment in intangible assets on labor productivity growth in the different considered EU countries, as well as what the implications in terms of industrial policy. To our knowledge, such kind of analysis has not been implemented for the manufacturing industry using data covering the Great Recession.

\section{Data and Methods}

\subsection{Data}

To carry out this study we use the EU KLEMS Growth and Productivity Accounts, 2019 release (EU KLEMS 2019) (henceforth EUKLEMS) ${ }^{1}$, which contain internationally comparable data for output and inputs, as well as for investment in intangible assets. This database includes a wide range of measures on output growth, employment, skill creation, capital formation and multi-factor productivity at the industrial level for EU member states from 1970 until 2018, and from 1995 to 2017 for data on investment in intangible assets.

Labor productivity measures are based on own elaboration and are defined in terms of hours worked, as well as all the variables needed for the analysis, where appropriate.

As Timmer et al. (2007a, 2007b) state, the main advantage of EU KLEMS database is that it allows its users to go beyond the aggregate level of economy to analyze the productivity performance of individual industries and their contribution to aggregate growth.

For more information on the source and details for measurement of intangible assets, see Corrado et al. (2014a, 2014b). Corrado et al. (2006) distinguish three classes of intangible assets:

- Computerized information: software and databases.

- Innovative property (scientific and non-scientific): R\&D, design (including architectural and engineering design), product development in the financial industry, exploration of minerals and production of artistic originals.

- Economic competencies: firm investment in reputation, human and organizational capital. 
Concerning investment in intangibles, we include all the variables belonging to these three classes of assets for which data are available for the considered period.

The data used in this research cover the period from 1995 to 2017 for a set of $18 \mathrm{EU}$ member states (Austria, Czechia, Denmark, Estonia, Finland, France, Germany, Latvia, Lithuania, Luxembourg, Italy, The Netherlands, Romania, Slovakia, Slovenia, Spain, Sweden, and United Kingdom). The criteria used to decide the time period as well as the countries chosen for this analysis rely on the availability of data. Thus, we have implemented in our study the latest data release available, so that a broad time span and geographical coverage of the EU is provided as we cover members of northern, central and southern Europe.

The criteria used to group countries into three groups is based in previous literature on the contribution of intangibles as generators of growth in Europe. In particular, we follow the classification by Piekkola (2017) who classifies European countries into three groups: (i) northern Europe (the Nordic countries (Denmark, Finland, Norway, and Sweden), the Baltic countries (Estonia, Latvia, and Lithuania), The Netherlands, and the UK); (ii) central Europe (Austria, Belgium, Czechia, France, Germany, and Slovakia); and (iii) southern Europe (Greece, Hungary, Italy, Romania, Slovenia, and Spain). We also considered Luxembourg, a country that has been classified as part of central Europe.

Table A1 (see Appendix A) displays the list of variables considered in the present analysis as well as information of variable definition and data sources. Table A2 (see Appendix A) also provides some descriptive statistics of the dataset used for the whole considered period. Concretely, this shows the average annual rate of change of the variables that intervene in our empirical analysis.

\subsection{Methods}

In order to estimate the contribution of investment in intangible assets to labor productivity, a log-linear Cobb-Douglas production function was used as the starting point. As in Roth and Thum (2013), a reduced form equation, in which the independent variable is the growth rate of investment in intangible assets and the dependent variable is labor productivity growth, can be easily derived from this theoretical model. The analysis is undertaken in growth rates and all variables are expressed in terms of logarithmic differences.

In particular, the change in the log of labor productivity of manufacturing in country $i$ between time $t$ and $t-1\left(L P_{i t}-L P_{i t-1}\right)$ is explained by the change of the different of intangible assets between time $t$ and $t-1,\left(X_{t}-X_{t-1}\right)$. The model is enlarged with country fixed effects $\left(C_{i}\right)$ that will account for potential unobserved heterogeneity and also with period effects $\left(Y_{t}\right)$ accounting for common shocks in the considered countries, while $U_{i t}$ is a random error term.

$$
L P_{i t}-L P_{i t-1}=\beta_{0}+\beta_{1}\left(X_{t}-X_{t-1}\right)+C_{i}+Y_{t}+U_{i t}
$$

The analysis is carried out on a sample of 18 countries for a period covering 23 years, conforming an unbalanced panel. So, the total number of observations would be 414 , but as far as there are a few missing values, the real number of observations varies across estimated models between 389 and 408. When the analysis is performed by groups of countries, the number of observations is as follows: northern Europe, between 170 and 178 observations ( 8 countries $\times 23$ years $=184$ observations); central Europe, between 133 and 138 ( 6 countries $\times 23$ years $=138$ observations); and southern Europe, between 88 and 92 ( 4 countries $\times 23$ years $=92$ observations). Table A1 (see Appendix A) displays the variables used in the present analysis.

The analysis is implemented in two steps. In both, we proceed in the same way; in the first phase, we start the analysis by introducing one by one the single intangible asset types belonging to each of the above defined classes of intangible assets, in order to find out if they are significant or not and to what extent they are contributors to labor productivity growth. In the second phase, we combine the significant independent variables and introduce them 
in the equation in order to find out how well or not they work together in increasing labor productivity.

In our analysis, we apply the same methodology for the whole sample of countries and each for the northern, central and southern group of countries. This grouping of countries has been decided by attending to a geographical criterion following Piekkola's (2017) analysis. Each column in Tables 1-4 presents a regression model including one type of asset and in the last columns, combinations of different type of assets that have been identified as relevant in the previous analysis.

\section{Results}

According to our data, real investment in intangible assets per hour worked grew at an annual average rate of 3.3 percent from 1995 to 2017 (see Table A2 in Appendix A). Software, although belonging to computerized information, one of the smallest categories of intangibles, was the fastest growing category in the period. It grew at an average annual rate of 14.6 percent, followed by scientific R\&D (from now on R\&D) with an average annual growth rate of 4.9 percent. Design (New architectural and engineering designs, new product development costs in the financial industry, entertainment, artistic and literary originals, and mineral exploration) grew at a slightly lower rate (4.5 percent).

In terms of investment per hour worked for the sample of countries considered in this study, these figures indicate that computerized information and innovative property represent a major part of investment in intangible assets. Thus, one may think that they are also major contributors to labor productivity growth in the 1995-2017 period. However, our findings do not provide support for this.

Table 1 reports the estimation results for all countries between 1995 and 2017. The analysis starts by estimating the contribution of both investment in intangible and tangible assets to labor productivity growth. The table also includes information about the influence of each single intangible asset type on the evolution of labor productivity. Finally, the significant independent variables are combined to test complementary effects.

The addition of all kinds of intangible assets seems not to contribute significantly to labor productivity growth in contrast to tangible capital, which turned out to be highly significant in our model.

However, the disaggregation of investment into different intangible assets provides a highly valuable contribution. It reveals that some sources of knowledge exert a positive influence on labor productivity. Similarly, to other previous studies, such as Roth (2020); Corrado et al. (2018); Hao et al. (2009); Roth and Thum (2013) or Corrado et al. (2014a), the investment in intangible assets improves labor productivity in manufacturing. Hypothesis $\mathrm{H} 1$ is confirmed.

When introducing the variables one by one in order to identify those intangible assets that are significant for labor productivity growth, we find out an unexpected result, which is that investment in software has no significant influence. The lacking influence of computerized information contrasts with the results obtained by other authors such as Corrado et al. (2013); Chun et al. (2012); and Van Ark and Jäger (2017), where ICT not only shows up a positive relation between labor productivity growth, but is complementary. One possible explanation may be that a minimum level of investment in software has been already achieved, so that additional investment is not significant. Brynjolfsson et al. (2002) confirm that what matters is the use, not the endowment. Once everyone is provided with the software, then the difference lies strictly in its strategic use.

Another unexpected result is the reduced influence of the single intangible components belonging to the innovative property category. Investment in R\&D is significant, but shows a moderate influence in promoting labor productivity growth $(0.187$ percentage points and is statistically significant at a 5\% level). In addition, the contribution of the other asset type (design), is not statistically significant. Consequently, innovative property assets are revealed as moderate contributors to labor productivity growth in European manufacturing. 
Table 1. Estimation results for all countries, 1995-2017.

\begin{tabular}{|c|c|c|c|c|c|c|c|c|c|c|}
\hline $\mathrm{TC}$ & $\begin{array}{c}0.235^{* * *} \\
(0.0636)\end{array}$ & - & - & - & $\begin{array}{l}- \\
-\end{array}$ & - & $\begin{array}{l}- \\
-\end{array}$ & - & $\begin{array}{l}0.206 \text { ** } \\
(0.0757)\end{array}$ & $\begin{array}{c}0.0879 * * \\
(0.0754)\end{array}$ \\
\hline \multirow[t]{2}{*}{$1 \mathrm{C}$} & - & & - & - & - & - & - & - & - & - \\
\hline & - & $(0.140)$ & - & - & - & - & - & - & - & - \\
\hline \multirow[t]{2}{*}{ SW } & - & - & $0.0594^{* *}$ & - & - & - & - & - & - & - \\
\hline & - & - & $(0.0866)$ & - & - & - & - & - & - & - \\
\hline \multirow[t]{2}{*}{ R\&D } & - & - & - & 0.187 * & - & - & - & - & - & $0.213^{* *}$ \\
\hline & - & - & - & $(0.0907)$ & - & - & - & - & - & $(0.0857)$ \\
\hline \multirow[t]{2}{*}{ DESIGN } & - & - & - & - & 0.155 & - & - & - & - & - \\
\hline & - & - & - & - & $(0.117)$ & - & - & - & - & - \\
\hline \multirow[t]{2}{*}{ ADV } & - & - & - & - & - & 0.0125 & - & - & - & - \\
\hline & - & - & - & - & - & $(0.125)$ & - & - & - & - \\
\hline \multirow[t]{2}{*}{ TRAIN } & - & - & - & - & - & - & $0.139^{* *}$ & - & - & $\begin{array}{c}0.00441 \\
* *\end{array}$ \\
\hline & - & - & - & - & - & - & $(0.0585)$ & - & - & $(0.0861)$ \\
\hline \multirow[t]{2}{*}{ ORGCAP } & - & - & - & - & - & - & - & 0.203 * & - & $0.188^{*}$ \\
\hline & - & - & - & - & - & - & - & $(0.113)$ & - & $(0.103)$ \\
\hline$N$ & 396 & 396 & 396 & 396 & 408 & 408 & 408 & 408 & 396 & 389 \\
\hline$R^{2}$ & 0.777 & 0.761 & 0.752 & 0.769 & 0.767 & 0.747 & 0.762 & 0.768 & 0.786 & 0.824 \\
\hline
\end{tabular}

Source: Own elaboration based on EU KLEMS, 2019 release (https: / / euklems.eu/; accessed on 29 March 2021). See Stehrer et al. (2019) for more details. Notes: Unbalanced panel, period 1995-2017, 18 countries (Austria, Czechia, Denmark, Estonia, Finland, France, Germany, Italy, Latvia, Lithuania, Luxemburg, The Netherlands, Romania, Slovak Republic, Slovenia, Spain, Sweden, United Kingdom). All specifications include country fixed effects and year fixed effects. Cluster Robust Standard errors in parentheses. ${ }^{*} p<0.10,{ }^{* *} p<0.05,{ }^{* * *} p<0.01$.

Turning now to the third category of intangible assets, economic competences, the organizational capital is by far the most significant variable among all the other considered in this study, jointly with vocational training. The contribution of organizational capital (0.203 points) exceeds the positive effect of R\&D investment on labor productivity. All three described asset types that make up economic competences display a distinctive result, together with an adjusted R-square value between 0.76 and 0.78 , which is an acceptable fit. Accordingly, these findings supply a positive verification of hypothesis H1a: Computerized information, innovative property and economic competences make a different contribution to the growth of labor productivity in manufacturing.

We also combine the significant independent variables and introduce them into the equation in order to find out whether they are complementary and how well they work together in increasing labor productivity. We start by combining the different significant assets with other assets belonging to their category, and afterwards with others belonging to the other intangible asset categories. When trying to assess the combined influence of more than one variable, a positive influence is detected from the interaction between $R \& D$ investment and organizational capital on labor productivity growth, accordingly to the results obtained by Brynjolfsson et al. (2002). The combination of innovative property assets and economic competences clearly accelerates labor productivity, contributing to a growth rate of 0.40 percentage points. Adjusted R-square value increases to 0.82 percentage points, which is a good fitting. H1b is fully corroborated. Here too, this result contrasts with the above-mentioned studies (Corrado et al. 2013, 2017a; Chun et al. 2012; Van Ark and Jäger 2017; Niebel et al. 2017).

Here again we reproduce the analysis previously undertaken on three different groups of countries: northern, central and southern European economies. The aim is to analyze whether different intangible investment strategies lead to a differentiated labor productivity growth and, thus, to a differentiated ability in generating gross value added. This would shed some light on why some countries display a better performance in labor productivity growth than others. We expect the latter to allow us to discriminate when defining and 
implementing policy measures to improve the performance of productivity. Ultimately, it would permit the design of concrete and targeted industrial policy measures, particularly for the countries lagging behind the ones showing a better performance.

Results are shown in Tables 2-4. The goodness of fit test reveals high values, ranging from 0.65 to 0.95 and the contribution of intangible assets is clearly different among the defined groups, confirming hypothesis H2. Different groups of countries follow different strategies to accumulate intangible assets, with a distinctive influence on the evolution of productivity in manufacturing. Results depend on country-specific characteristics. One possible explanation may be the specific characteristics of the manufacturing industry of the countries included in each group, as if in the considered period investment in this kind of intangible assets is relevant, because the needs are different, and they already have invested enough in the other asset types.

Considering the estimation results for northern European economies (Table 2), again here investment in intangibles is revealed as a driver for productivity growth, even stronger than the investment in tangible assets (0.31 percentage points compared to 0.18 ). For these economies, the investment in the different sources of knowledge encourages labor productivity. Considering the variables individually, the results show that computerized information, innovative property, and economic competences exert a positive influence. In particular, R\&D investment, followed by advertising and marketing and also software, is a major contributor to labor productivity growth. Vocational training is significant too, but at a significance level of $10 \%$. All the other variables considered, either individually or combined with others, are rejected because of the lack of statistical significance. These economies also get the most from the combination of the investment in both tangible and intangible assets, and also from the combination of different types of intangible assets. The investment in $R \& D$, together with computer software, provides the most favorable scenario for productivity growth (joint contribution of 0.28 percentage points). As this is the unique group of economies with a positive and significant influence of scientific R\&D on labor productivity growth, hypothesis $\mathrm{H} 2 \mathrm{a}$ is also verified. Northern European manufacturing shows the highest level of investment in this intangible asset, making the difference and providing a positive influence on labor productivity performance (Van Ark et al. 2009).

Examining the estimation results for central European countries (Table 3), a very different situation is detected. The growth in labor productivity during the 1995-2017 period is essentially the consequence of the heavy investment in tangible assets. The contribution of physical capital is exorbitant $(0.49$ percentage points, with a significance of $1 \%$ ) whereas the investment in tangible assets turns out not be significant. None of intangible assets become significant for the emergence of productivity growth. The high growth rate in capital investment of some eastern European economies would limit or make unnecessary the potential benefits from the investment in intangible assets, including scientific R\&D. Complementarity effects are not detected between both types of investment. Consequently, hypothesis $\mathrm{H} 2 \mathrm{~b}$ is fully verified, although the adjusted $\mathrm{R}$-square values here are somewhat lower (between 0.65 and 0.78 ).

The most outstanding outcomes from intangible assets investment are provided by southern Europe economies (Table 4). This kind of investment clearly explains the differences in labor productivity growth among the economies included in this group. Tangible and intangible assets contribute to the improvement of labor productivity with a similar strength ( 0.43 and 0.44 percentage points, respectively). However, complementary effects between both types of investment are not detected in our model.

Increasing investment in advertising and marketing, design, organizational capital, or software contributes the most to labor productivity growth in southern Europe. A combination of investment in computerized information and innovative property provides the most major effect on the evolution of labor productivity (joint influence of 0.58 percentage points). However, a combination of other intangible assets does not provide significant results, probably due to the high level of correlation between these investments. Here, 
some combinations of variables in an equation works out well together, but only when two variables are included; for more than two variables the equation is rejected.

Table 2. Estimation results for northern Europe.

\begin{tabular}{|c|c|c|c|c|c|c|c|c|c|c|}
\hline TC & $\begin{array}{l}0.183 \text { ** } \\
(0.0744)\end{array}$ & - & - & - & - & - & - & - & $\begin{array}{c}0.135^{*} \\
(0.0643)\end{array}$ & $\begin{array}{c}-0.0714 \\
(0.0546)\end{array}$ \\
\hline \multirow[t]{2}{*}{ IC } & - & $0.307^{* *}$ & - & - & - & - & - & - & 0.253 * & - \\
\hline & - & $(0.119)$ & - & - & - & - & - & - & $(0.116)$ & - \\
\hline \multirow[t]{2}{*}{ SW } & - & - & $0.155^{* * *}$ & - & - & - & - & - & - & $0.0639 * *$ \\
\hline & - & - & $(0.0440)$ & - & - & - & - & - & - & $(0.0190)$ \\
\hline \multirow[t]{2}{*}{$\mathrm{R} \& D$} & - & - & - & $0.223^{* * *}$ & - & - & - & - & - & $0.220^{* * *}$ \\
\hline & - & - & - & $(0.0509)$ & - & - & - & - & - & $(0.0557)$ \\
\hline \multirow[t]{2}{*}{ DESIGN } & - & - & - & - & $0.0497 *$ & - & - & - & - & - \\
\hline & - & - & - & - & $(0.110)$ & - & - & - & - & - \\
\hline \multirow[t]{2}{*}{ ADV } & - & - & - & - & - & $0.219^{*}$ & - & - & - & -0.00375 \\
\hline & - & - & - & - & - & (0.110) & - & - & - & $(0.0382)$ \\
\hline \multirow[t]{2}{*}{ TRAIN } & - & - & - & - & - & - & $0.142 *$ & - & - & -0.00763 \\
\hline & - & - & - & - & - & - & $(0.0698)$ & - & - & $(0.0616)$ \\
\hline \multirow[t]{2}{*}{ ORGCAP } & - & - & - & - & - & - & - & 0.212 & - & - \\
\hline & - & - & - & - & - & - & - & $(0.126)$ & - & - \\
\hline$N$ & 175 & 175 & 175 & 170 & 178 & 178 & 178 & 178 & 175 & 170 \\
\hline$R^{2}$ & 0.886 & 0.894 & 0.910 & 0.936 & 0.867 & 0.877 & 0.875 & 0.885 & 0.906 & 0.945 \\
\hline
\end{tabular}

Source: Own elaboration based on EU KLEMS, 2019 release (https: / / euklems.eu/; accessed on 29 March 2021). See Stehrer et al. (2019) for more details. Notes: Unbalanced panel, period 1995-2017, 8 countries (Denmark, Estonia, Finland, Latvia, Lithuania, The Netherlands, Sweden, United Kingdom). All specifications include country fixed effects and year fixed effects. Cluster Robust Standard errors in parentheses. ${ }^{*} p<0.10,{ }^{* *} p<0.05,{ }^{* * *} p<0.01$.

Table 3. Estimation results for central Europe.

\begin{tabular}{|c|c|c|c|c|c|c|c|c|c|c|}
\hline $\mathrm{TC}$ & $\begin{array}{c}0.491^{* *} \\
(0.126)\end{array}$ & - & $\begin{array}{l}- \\
-\end{array}$ & $\begin{array}{l}- \\
-\end{array}$ & $\begin{array}{l}- \\
-\end{array}$ & $\begin{array}{l}- \\
-\end{array}$ & - & $\begin{array}{l}- \\
-\end{array}$ & $\begin{array}{c}0.416^{* *} \\
(0.106)\end{array}$ & $\begin{array}{c}0.356^{* *} \\
(0.112)\end{array}$ \\
\hline IC & - & $\begin{array}{c}-0.355 \\
(0.244)\end{array}$ & $\begin{array}{l}- \\
-\end{array}$ & $\begin{array}{l}- \\
-\end{array}$ & $\begin{array}{l}- \\
-\end{array}$ & $\begin{array}{l}- \\
-\end{array}$ & $\begin{array}{l}- \\
-\end{array}$ & $\begin{array}{l}- \\
-\end{array}$ & $\begin{array}{c}-0.225 \\
(0.206)\end{array}$ & - \\
\hline \multirow[t]{2}{*}{ SW } & - & - & $\begin{array}{c}-0.190 \\
* *\end{array}$ & - & - & - & - & - & - & - \\
\hline & - & - & $(0.0596)$ & - & - & - & - & - & - & - \\
\hline \multirow[t]{2}{*}{$R \& D$} & - & - & - & 0.328 & - & - & - & - & - & - \\
\hline & - & - & - & $(0.261)$ & - & - & - & - & - & - \\
\hline \multirow[t]{2}{*}{ DESIGN } & - & - & - & - & 0.238 & - & - & - & - & - \\
\hline & - & - & - & - & $(0.359)$ & - & - & - & - & - \\
\hline \multirow[t]{2}{*}{ ADV } & - & - & - & - & - & $-\underset{* *}{0.231}$ & - & - & - & -0.0531 \\
\hline & - & - & - & - & - & $(0.0805)$ & - & - & - & $(0.0651)$ \\
\hline \multirow[t]{2}{*}{ TRAIN } & - & - & - & - & - & - & 0.644 & - & - & - \\
\hline & - & - & - & - & - & - & $(0.438)$ & - & - & - \\
\hline \multirow[t]{2}{*}{ ORGCAP } & - & - & - & - & - & - & - & -0.164 & - & - \\
\hline & - & - & - & - & - & - & - & $(0.186)$ & - & - \\
\hline$N$ & 133 & 133 & 133 & 136 & 138 & 138 & 138 & 138 & 133 & 133 \\
\hline$R^{2}$ & 0.698 & 0.666 & 0.725 & 0.689 & 0.665 & 0.686 & 0.678 & 0.647 & 0.713 & 0.775 \\
\hline
\end{tabular}

Source: Own elaboration based on EU KLEMS, 2019 release (https: / / euklems.eu/; accessed on 29 March 2021). See Stehrer et al. (2019) for more details. Notes: Unbalanced panel, period 1995-2017, 6 countries (Austria, Czechia, France, Germany, Luxembourg, Slovak Republic). All specifications include country fixed effects and year fixed effects. Cluster Robust Standard errors in parentheses. ${ }^{*} p<0.10,{ }^{* *} p<0.05$, *** $p<0.01$. 
Table 4. Estimation results for southern Europe.

\begin{tabular}{|c|c|c|c|c|c|c|c|c|c|c|}
\hline TC & $\begin{array}{c}0.425^{* * *} \\
(0.0478)\end{array}$ & - & - & - & - & - & - & - & $\begin{array}{c}0.153 * \\
(0.0915)\end{array}$ & - \\
\hline \multirow[t]{2}{*}{ IC } & - & $0.437^{* * *}$ & - & - & - & - & - & - & $0.356^{* *}$ & - \\
\hline & - & $(0.0621)$ & - & - & - & - & - & - & $(0.0874)$ & - \\
\hline \multirow[t]{2}{*}{ SW } & - & - & $0.247^{* * *}$ & - & - & - & - & - & - & 0.144 * \\
\hline & - & - & $(0.0419)$ & - & - & - & - & - & - & $(0.0610)$ \\
\hline \multirow[t]{2}{*}{ R\&D } & - & - & - & $-0.462 *$ & - & - & - & - & - & - \\
\hline & - & - & - & $(0.171)$ & - & - & - & - & - & - \\
\hline \multirow[t]{2}{*}{ DESIGN } & - & - & - & - & 0.412 *** & - & - & - & - & -0.0887 \\
\hline & - & - & - & - & $(0.0659)$ & - & - & - & - & $(0.0379)$ \\
\hline \multirow[t]{2}{*}{ ADV } & - & - & - & - & - & $0.542^{* * *}$ & - & - & - & $0.431^{* *}$ \\
\hline & - & - & - & - & - & $(0.0549)$ & - & - & - & $(0.122)$ \\
\hline \multirow[t]{2}{*}{ TRAIN } & - & - & - & - & - & - & 0.152 & - & - & - \\
\hline & - & - & - & - & - & - & $(0.155)$ & - & - & - \\
\hline \multirow[t]{2}{*}{ ORGCAP } & - & - & - & - & - & - & - & $0.396^{* * *}$ & - & - \\
\hline & - & - & - & - & - & - & - & $(0.0484)$ & - & - \\
\hline$N$ & 88 & 88 & 88 & 90 & 92 & 92 & 92 & 92 & 88 & 88 \\
\hline$R^{2}$ & 0.850 & 0.912 & 0.909 & 0.813 & 0.900 & 0.922 & 0.800 & 0.916 & 0.921 & 0.943 \\
\hline
\end{tabular}

Source: Own elaboration based on EU KLEMS, 2019 release https:/ / euklems.eu/; accessed on 29 March 2021). See Stehrer et al. (2019) for more details. Notes: Unbalanced panel, period 1995-2017, 4 countries (Italy, Romania, Slovenia, Spain). All specifications include country fixed effects and year fixed effects. Cluster Robust Standard errors in parentheses. ${ }^{*} p<0.10,{ }^{* *} p<0.05,{ }^{* * *} p<0.01$.

Southern European economies, including Romania and Slovenia, are highly dependent on intangible investment to accelerate labor performance, confirming hypothesis $\mathrm{H} 2 \mathrm{c}$. The individual and joint contribution of intangible assets to the growth of productivity in manufacturing is higher among this group of countries. Only the investment in R\&D provides an unexpected result, with a negative contribution, revealing that this type of investment does not promote the acceleration and convergence of productivity levels in these economies.

\section{Discussion}

Some findings have emerged according to the posed hypotheses and research questions. Empirical analysis reveals that all single intangible assets are significant contributors to labor productivity growth in these countries in the considered period. However, a simple splitting of countries intro three geographical blocks is enough to identify a significant differentiated behavior between groups. Heterogeneous effects of investment in intangibles on labor productivity growth have been clearly verified.

In addition, inside each group, intangible investment figures also display a differentiated evolution (Table A2 in Appendix A), supporting the fact that differences in intangible assets may explain not only heterogeneity among the groups, but also inside them. In fact, higher investment rates in intangible assets do not necessarily imply that those assets become major drivers of labor productivity growth. Thus, our results reflect the different needs in terms of investment in intangibles aimed at promoting labor productivity growth of the countries pertaining to each block.

Concerning the different classes of intangible assets, for a long time, R\&D activities and innovative property have been traditionally viewed as the main drivers of innovation. The Lisbon Strategy, the Horizon 2020 Strategy, and the European Round Table of Industrialists (2017) point out the importance of R\&D and innovation explicitly. Consequently, they have been disproportionately encouraged by governments over of other intangible assets that are increasingly revealed as equally or more relevant than R\&D to labor productivity growth. As Muntean (2014) states, governments around the world provide significant support for innovative activities in the manufacturing industry. 
Our findings support the positive influence of $R \& D$ investment on the evolution of labor productivity. However, similarly to Roth and Thum (2013), our results also show that innovative property is not necessarily the main driver of labor productivity growth, as expected from the guidelines of the Europe 2020 Strategy (European Commission 2010), but rather, economic competencies. One of the main criticisms of measuring innovation through investment in R\&D is that it does not seem to be a valid indicator for a country's innovativeness. It is certainly an appropriate indicator in countries with a strong manufacturing industry (northern Europe), but not in those countries with a high specialization in service activities, in which design activities are revealed to be becoming more decisive in improving productivity (southern Europe).

Previous studies examining the contribution of the different categories of intangibles to labor productivity growth had shown their significance, suggesting that focusing solely on R\&D might not provide a complete view of innovation. Bauer et al. (2020, pp. 14-15) and Roth (2020) summarize a wide range of studies on the impact of capital investment in intangible assets on labor productivity growth. As the Horizon 2020 Strategy and the European Commission (2013b) recognize, intangible capital is the major determinant of innovation followed by $R \& D$, which has been revealed to be no longer such an important driver of innovation as initially considered. Thus, it is important to precisely target the different innovation measures in the Horizon 2020 Strategy in order to obtain the best results when it comes to foster innovation in the EU.

In particular, our findings reveal that more importance should be placed on the intangible assets included in the economic competencies category. This raises the question on how to invest strategically in those intangible assets that are major contributors to labor productivity growth. As Muntean (2014) states, empirical studies of intangible capital (Van Ark et al. 2009; Jona Lasinio et al. 2011; Roth and Thum 2011, 2013) indicate that other categories of intangibles, such as vocational training, advertising and marketing (brand equity) and organizational capital also contribute significantly to labor productivity growth. Our results confirm these previous findings, particularly for southern European economies.

Concerning vocational training, skills feature as a major policy element in the Europe 2020 agenda. The European Commission (2010) implemented an overall strategy for improving education and training systems via anticipation and investment in human capital supported by EU financial instruments, tools to monitor skills and training needs and trends, and specific initiatives to bring together the relevant actors. There are significant differences in the skills, the achievements and the effectiveness of vocational training systems across member states. The contribution of apprenticeships in supporting industrial competitiveness is widely recognized. Large differences in the skills, the achievements and the effectiveness of vocational training systems across member states correlate with acute unemployment in crisis-hit member states. To invest in this intangible asset will positively influence advertising and marketing, and organizational capital, as far as human capital is strongly related to these intangible assets. So, higher skills will result in an improved performance of these two assets.

As Cañibano et al. (2000) demonstrated, the ownership of a brand that is attractive for the customers allows the sellers to obtain a higher margin for goods or services, which are similar to those offered by the competitors. Thus, the development of a brand becomes a key element in obtaining future benefits. Expenditure on market research and advertising constitutes an important part of the investment in brand equity (Roth and Thum 2013). Presently, the management of the production process involves highly technological physical capital, which requires highly qualified workers. In such a context, the quality of the training of the workers becomes relevant. As far as goods become more elaborated and incorporate more high-intensity technology, production processes are becoming more complex. Thus, the training of the workers becomes crucial. As Cañibano et al. (2000) and Abowd et al. (2005) argue, a firm with better qualified workers is expected to obtain higher profits than other ones with less-skilled employees. In addition, a firm with highly quali- 
fied human resources will have a higher value than other companies with less-qualified employees (Roth and Thum 2013).

The influence of computerized information on productivity growth is also positive, although its contribution is less decisive. A plausible explanation may be that once a certain level of investment in software has been already achieved, additional investment is not so significant. As Brynjolfsson et al. (2002) state that once the necessary requirements of software have been achieved, then the difference lies strictly in its strategic use.

According to Bresnahan et al. (2002), organizational change should accompany ICT adoption in order to boost labor productivity growth. It appears that, although computerized information is the intangible asset showing the highest investment rates between 1995 and 2017, it only has turned out to be a significant contributor together with organizational capital to labor productivity growth for southern Europe economies and with R\&D investment for northern Europe economies. In line with other authors, such as Corrado et al. (2013); Chun et al. (2012) or Van Ark and Jäger (2017), ICT shows up also a positive complementary influence with other intangible assets.

Regarding industrial policy recommendations, as the characteristics of the countries inside each group are not homogenous enough to define only common measures addressing the improvement of labor productivity growth, it is difficult to propose homogenous industrial policy measures for the countries belonging to each group aiming to improve their performance. For this reason, different policy measures attaining to the differentiated needs in terms of intangible investment of the considered EU member states should be implemented.

European countries differ significantly in how heavily they invest in intangible assets (Roth 2020; Corrado et al. 2013, 2018; Niebel et al. 2017; Peiró-Palomino 2016) and this is also reflected in their differentiated contribution to labor productivity growth, as our results show. This hinders drawing a common pattern in their behavior when it comes to defining a unique policy measure to improve labor productivity growth by means of increasing intangible investment. It requires a new model of innovation and technological change, helping countries to make better use of their own innovative capabilities (Timmer et al. 2011). Investment in intangible assets, such as advertising and marketing, vocational training, and organizational capital, as well as other intangible investments, are closely related to each country's needs, that is, they are specific to individual firms. It is the firm that receives most of the benefits of such changes.

In this context, the main conclusion concerning the implications in terms of industrial policy is that homogeneous policy measures at EU level should be combined with specific measures focusing on the member states' needs when it comes to promoting intangible investment. In other words, defining the same industrial policy measures for the different countries might not result in the expected objectives. By nature, capital investment is highly volatile and very sensitive to changes in the economic conditions of the different countries. The tides and waves of investment usually follow business cycle expansions and downturns. This means that policy measures should be designed focusing on the specific needs of investment in intangibles of the single countries. As Blind and Georghiou (2010) state, research and innovation policy, as well as other innovation-related policies, should be coordinated at regional, national, and European levels to maximize the benefits and minimize the cost. The commitment to innovation and the recognition that a knowledgedriven approach is fundamental to meet the goals of economic recovery, social development and sustainability has led to a number of promising initiatives. There is evidence (European Commission 2020; Dhéret 2014; Pianta 2013) that Europe is not exploiting its innovation potential and that significant barriers are rooted in a lack of coordination between different policy initiatives and regulatory frameworks in both vertical and horizontal dimensions. The vertical issue concerns coordination and effective subsidiarity among the European, national, and regional levels, while the horizontal is concerned with bringing together the policies and institutions rooted in sectoral and regulatory domains, but which are critical for innovation and the effective functioning of markets. 
Our results are in line with those obtained by other authors; that the influence of intangible investment on the different EU member economies is heterogeneous. For example, Peiró-Palomino (2016, pp. 190-92) shows that the "different endowments of intangible assets might explain the differences in regional performance, as well as possibly affect the regional income convergence process and condition the success of the Cohesion Policy". Thus a "more egalitarian regional distribution of these assets would slightly improve the relative position of the poorest regions, ...". The latter shows the need for specific policy measures in order to reduce the disparities in terms of these assets, as investment in intangibles influences the relative position of the economies in terms of income. It is certain that common measures can be designed for each group of countries, but to obtain better positive results, they should be complemented with other specific measures focusing on the concrete problems of each member state.

The technological endowment and capabilities as well as the degree of investment in intangible assets (Peiró-Palomino 2016) of the EU member states would explain to a great extent their heterogeneous dynamics of convergence. Different studies show that the country's dummy estimates on regional convergence tend to be significant, but they display very different coefficients, indicating the presence of different steady states linked to the intrinsic characteristics of each country (Petrakos et al. 2011; Bos et al. 2010). This sustains that measures promoting investment in intangibles at EU level should be accompanied by specific measures focusing each country's needs for the purpose of promoting labor productivity growth.

According to the European Competitiveness Report (2013), in the EU too little has been invested in the skill and organizational changes necessary to reap the benefits of ICT technologies. Lower investments in intangible assets ( $\&$ D, human capital, etc.) are likely to explain slow labor productivity growth, as these factors affect a country's ability to take advantage of technology developed elsewhere.

Given that the bulk of technological innovations is concentrated on a few leading countries, improvements by the lagging countries in the absorptive capacity will be needed in order to assimilate foreign technologies. The empirical results show that ICT plays a key role in reducing inefficiencies in the use of resources. In addition, more upstream regulation significantly increases the efficiency gap. In other words, administrative restrictions imposed on service market competition have widespread negative effects on production efficiency.

These results provide strong support for the hypothesis that a more competitive business environment could reduce the efficiency gap, promoting economic competences. More flexible product market regulations, largely concentrated in key service-providing industries, are likely to raise efficiency levels across the whole economy. Regulatory changes in the labor market should also be tailored to restore the necessary balance between regular and temporary workers.

\section{Concluding Remarks}

This study has explored the influence of different intangible assets' investment on labor productivity growth, using international comparable panel data on the manufacturing industry for $18 \mathrm{EU}$ member states within a panel analysis between 1995 and 2017.

The main findings can be summarized as follows. The three different categories of intangible assets make a distinctive contribution to the evolution of productivity. In particular, intangible assets related to economic competences together with innovative property assets have been identified as the main drivers for labor productivity growth. Among the variables considered significant, advertising and marketing, organizational capital, R\&D investment, and design are the ones which contribute individually the most to productivity growth in European manufacturing, meanwhile computerized information reveals their complementary effect with other intangible assets.

The splitting of the sample into three different geographical groups confirms a differentiated behavior in terms of labor productivity growth and intangible investment 
between and within the blocks. Investment in tangible assets is critical to justify differences in productivity growth among northern or southern European economies, but not for central Europe. A complementary effect of the investment in both tangible and intangible assets is detected only for northern European economies and some economies with a high rate of investment in intangible assets (such as Luxemburg) do no display a significant improvement in labor productivity.

The implications of these findings for the design of industrial policy are that common measures should be combined with specific ones focusing on the particular needs in terms of intangible investment in each country. A plausible explanation is provided by the heterogeneity of the characteristics of the different countries included in each group (Peiró-Palomino 2016). Such diversity within each group needs concrete targeted solutions to problems shown up by each country to improve their labor productivity growth's performance. Thus, it is difficult to label the considered groups according to investment in intangibles or to a geographic criterion, in order to design a single common industrial policy for the whole sample.

Our findings provide evidence for updating the present policy frameworks in order to take into account the relevance of intangible capital, and are in line with those recently shown in Bauer et al. (2020) and Roth (2020). Evidence suggests that the solution for the innovation deficit of some European economies consists not only of raising R\&D expenditure across all types of industries of the EU member states (Piekkola 2011). To do this, policies need to address specific barriers to innovation (European Commission 2020). Firstly, a general innovation policy is necessary to improve the environment for innovation. Measures facilitating the interaction among innovators and addressing the lack of young firms in young R\&D-intensive sectors should aim to ease the interaction of the players in the innovation system and to promote competition. Secondly, it is necessary to introduce policy measures that tackle the concrete barriers that new firms have to deal with in new sectors, such as the access to external financing for highly innovative projects.

Author Contributions: Conceptualisation, formal analysis, methodology, data curation, econometric analysis, validation, writing the original draft, review and editing: C.H. and R.R. Conceptualisation, formal analysis, methodology, writing the original draft, review and editing J.L.-M. All authors have read and agreed to the published version of the manuscript.

Funding: This research received no external funding.

Institutional Review Board Statement: Not applicable.

Informed Consent Statement: Not applicable.

Data Availability Statement: Data used in this article is freely available at https://euklems.eu/ [accessed on 29 March 2021].

Conflicts of Interest: The authors declare no conflict of interest. 


\section{Appendix A}

Table A1. Variable description, 1995-2017.

\begin{tabular}{lll}
\hline \multicolumn{1}{c}{ Variable Description } & & Acronym \\
\hline Labor productivity & Real value added per hour worked & LP \\
Investment in tangible assets & - & TC \\
Investment in intangible assets & - & IC \\
Investment in Computer software & - & SW \\
Investment in Innovative Property & - Scientific R\&D & R\&D \\
& - New architectural and engineering designs, New product & DESIGN \\
& development costs in the financial industry Entertainment, & ADV \\
Investment in Economic Competencies & Artistic and Literary Originals and Mineral Explorations & TRAIN \\
& - Market research and Advertising expenditure & ORGCAP \\
\hline
\end{tabular}

Notes: Data source for all variables is EU-KLEMS: https://euklems.eu/; (accessed on 29 March 2021). Except labor productivity, all monetary variables are expressed in millions of Euros at constant prices $(2010=100)$. Total hours worked by persons engaged are expressed in millions. Labor productivity is expressed in millions of Euros per millions of hours worked. Source: Own elaboration on Corrado et al. (2014a, 2014b).

Table A2. Labor productivity growth and investment in intangibles. Average year-on-year growth rates 1995-2017.

\begin{tabular}{|c|c|c|c|c|c|c|c|c|c|}
\hline $\begin{array}{l}\text { Countries-Groups } \\
\text { (First Column)/Variables } \\
\text { (First Row) Title }\end{array}$ & LP & TC & IC & SW & R\&D & DESIGN & ADV & TRAIN & ORGCAP \\
\hline TOTAL & 4.00 & 4.43 & 3.34 & 14.57 & 4.88 & 4.46 & 3.38 & 0.84 & 2.96 \\
\hline NORTH & 4.30 & 4.83 & 2.84 & 10.85 & 5.73 & 4.32 & 2.28 & 0.37 & 2.40 \\
\hline Denmark (DK) & 2.96 & 3.48 & 4.21 & 11.12 & 7.45 & 7.33 & 1.67 & 0.04 & 2.13 \\
\hline Estonia (EE) & 6.94 & 9.64 & 4.51 & 34.40 & 15.02 & 8.09 & 3.87 & 2.03 & 4.79 \\
\hline Finland (FI) & 3.92 & -0.79 & 1.98 & 5.81 & 0.89 & 1.71 & 1.30 & 0.24 & 2.69 \\
\hline Lithuania (LT) & 6.70 & 11.36 & 4.85 & 21.78 & 10.33 & 4.76 & 1.95 & 0.01 & 3.66 \\
\hline Latvia (LV) & 4.40 & 7.91 & -1.11 & 0.47 & 13.18 & 1.24 & 0.13 & 1.13 & -0.34 \\
\hline Sweden (SE) & 4.23 & -0.52 & 5.21 & 4.15 & 0.53 & 5.29 & 4.11 & 0.12 & 8.18 \\
\hline United Kingdom (UK) & 2.37 & 7.59 & -1.29 & 0.13 & 1.29 & 2.09 & 1.69 & 1.24 & -4.95 \\
\hline CENTRAL & 4.03 & 3.81 & 3.92 & 19.18 & 3.79 & 4.94 & 5.34 & 0.87 & 4.00 \\
\hline Austria (AT) & 3.01 & 3.65 & 4.41 & 7.33 & 5.24 & 7.90 & 3.57 & 0.57 & 1.76 \\
\hline Czechia (CZ) & 5.83 & 3.77 & 1.93 & 3.00 & 4.55 & 1.91 & -0.33 & 2.93 & 3.13 \\
\hline Germany (DE) & 2.60 & 1.57 & 2.20 & 5.64 & 2.18 & 3.31 & 0.32 & 1.03 & 1.92 \\
\hline France (FR) & 3.13 & 1.23 & 2.08 & 2.48 & 2.09 & 2.52 & 1.54 & -0.98 & 3.42 \\
\hline Luxembourg (LU) & 1.39 & 2.45 & 8.91 & 72.46 & 3.98 & 3.82 & 27.38 & -0.31 & 11.68 \\
\hline The Netherlands (NL) & 2.78 & 0.91 & 3.30 & 6.89 & 0.45 & 3.38 & 2.98 & -1.65 & 2.44 \\
\hline Slovakia (SK) & 8.20 & 12.10 & 4.06 & 25.63 & 4.67 & 10.17 & -0.46 & 1.99 & 2.10 \\
\hline SOUTH & 3.40 & 4.59 & 3.42 & 15.05 & 4.93 & 4.01 & 2.60 & 1.69 & 2.50 \\
\hline Spain (ES) & 1.69 & 3.18 & 1.19 & 8.33 & 5.36 & 1.87 & 1.20 & -1.26 & -0.85 \\
\hline Italy (IT) & 1.32 & 1.74 & 0.54 & 1.56 & 3.88 & 0.49 & -0.08 & -0.57 & 0.94 \\
\hline Romania (RO) & 5.63 & 8.46 & 10.02 & 46.07 & 6.05 & 8.46 & 6.68 & 13.36 & 7.92 \\
\hline Slovenia (SI) & 4.96 & 5.44 & 2.73 & 8.17 & 4.50 & 5.22 & 2.59 & -4.77 & 1.97 \\
\hline
\end{tabular}

Source: See Table A1 for variable definitions. Own elaboration based on EU KLEMS, 2019 release https://euklems.eu/; accessed on 29 March 2021). See Stehrer et al. (2019) for more details.

\section{Notes}

1 For a detailed description of the data, see Timmer et al. (2007a, 2007b), and for the previous EU KLEMS database up to the 2017 release (revised July 2018), see http: / / www.euklems.net and https:/ / euklems.eu/ for the 2019 release (both accessed on 29 March 2021).

\section{References}

Abowd, John M., John Haltiwanger, Ron Jarmin, Julia Lane, Paul Lengermann, Kristin McCue, Kevin McKinney, and Kristin Sandusky. 2005. The Relation Among Human Capital, Productivity and Market Value: Building Up from Micro Evidence. In Measuring Capital in the New Economy. Edited by Corrado Carol, Haltiwanger John and Sichel Daniel. Chicago: University of Chicago Press, pp. 153-204.

Aiginger, Karl, and Dani Rodrik. 2020. Rebirth of Industrial Policy and an Agenda for the Twenty-First Century. Journal of Industry, Competition and Trade 20: 189-207. [CrossRef] 
Baldwin, John R., Wulong Gu, and Ryan Macdonald. 2012. Intangible Capital and Productivity Growth in Canada. The Canadian Productivity Review 29: 1-44. [CrossRef]

Barnes, Paula, and Andrew McClure. 2009. Investments in Intangible Assets and Australia's Productivity Growth. Productivity Commission Staff Working Paper, March 26.

Bauer, Peter, Igor Fedotenkov, Aurelien Genty, Issam Hallak, Peter Harasztosi, David Martínez Turégano, David Nguyen, Nadir Preziosi, Ana Rincon-Aznar, and Miguel Sanchez-Martinez. 2020. Productivity in Europe-Trends and Drivers in a Service-Based Economy. EUR 30076 EN. Luxembourg: Publications Office of the European Union, ISBN 978-92-76-10610-4. JRC119785. Available online: https:/ / www.europarl.europa.eu/news/en/headlines/economy/20201112STO91445/new-eu-industrial-strategy-thechallenges-to-tackle (accessed on 1 June 2020). [CrossRef]

Belhocine, Nazim. 2009. Treating Intangible Inputs as Investment Goods: The Impact on Canadian GDP. IMF Working Paper, November 1.

Bisztray, Márta, Bálazs Muraközy, and Dzsamila Vonnák. 2020. Analysis of the Importance of Intangible Capital for Productivity Measurement. Deliverable D1.5. Microprod Project-Raising EU Productivity: Lessons from Improved Micro Data. Available online: http:/ / www.microprod.eu/wp-content/uploads/2020/02/MICROPROD-D1.5-Analysis-of-the-importance-ofintangible-capital-2020-02-04-V1.0.pdf (accessed on 1 December 2019).

Blind, Knut, and Luke Georghiou. 2010. Drivers and Impediments for Innovation in Europe. Intereconomics 45: 264-86. [CrossRef]

Borgo, Mariela Dal, Peter Goodridge, Jonathan Haskel, and Annarosa Pesole. 2013. Productivity and growth in UK industries: An intangible investment approach. Oxford Bulletin of Economics and Statistics 75: 806-34. [CrossRef]

Bos, Jaap W. B., Claire Economidou, and Michael Koetter. 2010. Technology Clubs, R\&D and Growth Patterns: Evidence form EU Manufacturing. European Economic Review 54: 60-79.

Bounfour, Ahmed, and Tsutomu Miyagawa. 2015. Intangibles, Market Failure and Innovation Growth. Heidelberg: Springer, pp. 1-10.

Bresnahan, Timothy F., Erik Brynjolfsson, and Lorin M. Hitt. 2002. Information Technology, Work-place Organization and the Demand for Skilled Labor: Firm-level Evidence. Quarterly Journal of Economics 117: 339-76. [CrossRef]

Brynjolfsson, Erik, Lorin M. Hitt, and Shinkyu Yang. 2002. Intangible Assets: Computers and Organizational Capital. Brookings Papers on Economic Activity 2001: 137-98. [CrossRef]

Brynjolfsson, Erik, Daniel Rock, and Chad Syverson. 2017. Artificial Intelligence and the Modern Productivity Paradox: A Clash of Expectations and Statistics. Cambridge: National Bureau of Economic Research, US Department of Commerce, p. w24001. Available online: http:/ / www.nber.org/papers/w24001.pdf (accessed on 1 June 2020).

Cañibano, Leandro, Manuel García-Ayuso, and M. Paloma Sánchez. 2000. Accounting for Intangibles: A Literature Review. Journal of Accounting Literature 19: 102-30.

Chun, Hyunbae, Kyoji Fukao, Shoichi Hisa, and Tsutomu Miyagawa. 2012. Measurement of Intangible Investments by Industry and Its Role in Productivity Improvement Utilizing Comparative Studies between Japan and Korea; RIETI Discussion Paper Series 12037; The Research Institute of Economy, Trade and Industry. Available online: http://www.rieti.go.jp/jp/publications/dp/12e037.pdf (accessed on 1 May 2020).

Coad, Alexander, and Antonio Vezzani. 2017. Manufacturing the Future: Is the Manufacturing Sector a Driver of R\&D, Exports and Productivity Growth? JRC Working Papers on Corporate R\&D and Innovation 6/2017. Available online: https:/ / ec.europa.eu / jrc\%0A (accessed on 1 May 2020).

Coe, David T., and Elhanan Helpman. 1995. International R\&D Spillovers. European Economic Review 39: 859-87.

Corrado, Carol, Charles Hulten, and Daniel Sichel. 2005. Measuring Capital and Technology: An Expanded Framework. In Measuring Capital in the New Economy. Edited by Corrado Carol, Haltiwanger John and Sichel Daniel. Chicago: The University of Chicago Press, pp. 11-45.

Corrado, Carol, Charles Hulten, and Daniel Sichel. 2006. Intangible Capital and Economic Growth. NBER Working Paper 11948. Cambridge: National Bureau of Economic Research.

Corrado, Carol, Charles Hulten, and Daniel Sichel. 2009. Intangible capital and US economic growth. Review of Income and Wealth 55: 661-85. [CrossRef]

Corrado, Carol, Jonathan Haskel, Cecilia Jona-Lasinio, and Massimiliano Iommi. 2013. Innovation and intangible investment in Europe, Japan, and the United States. Oxford Review of Economic Policy 29: 261-86. [CrossRef]

Corrado, Carol, Jonathan Haskel, Cecilia Jona-Lasinio, and Massimiliano Iommi. 2014a. Intangibles and Industry Productivity Growth: Evidence from the EU: Intan-Invest. (July). pp. 1-30. Available online: http:/ /www.coinvest.org.uk/pub/IntanInvest/ WebHome/INTAN-Invest_Harmonized_Industry_Estimates.pdf (accessed on 1 May 2020).

Corrado, Carol, Jonathan Haskel, Cecilia Jona-Lasinio, and Massimiliano Iommi. 2014b. Internationally Comparable Macro-Estimates of Investment in Intangible Assets at the Industry Level: Intan-Invest. Available online: www.INTAN-Invest.net (accessed on 1 May 2020).

Corrado, Carol, Jonathan Haskel, and Cecilia Susanna Jona-Lasinio. 2016a. Intangibles, ICT and industry productivity growth: Evidence from the EU. In The World Economy: Growth or Stagnation? Cambridge: Cambridge University Press, pp. 319-46. [CrossRef]

Corrado, Carol, Jonathan Haskel, Cecilia Jona-Lasinio, and Massimiliano Iommi. 2016b. Intangible Investment in the EU and US before and Since the Great Recession and Its Contribution to Productivity Growth. EIB Working Papers 2016/08. Luxembourg: European Investment Bank (EIB). 
Corrado, Carol, Haskel Jonathan, Massimiliano Iommi, Cecilia Susanna Jona-Lasinio, Mas Matilde, and O’Mahony Mary. 2017a. Advancements in Measuring Intangibles for European Economies. In Eurostat Review on National Accounts and Macroeconomic Indicators. Luxembourg: Publications Office of the European Union, pp. 89-106.

Corrado, Carol, Jonathan Haskel, and Cecilia Jona-Lasinio. 2017b. Knowledge Spillovers, ICT and Productivity Growth. Oxford Bulletin of Economics and Statistics 79: 592-618. [CrossRef]

Corrado, Carol, Jonathan Haskel, Cecilia Jona-Lasinio, and Massimiliano Iommi. 2018. Intangible investment in the EU and US before and since the Great Recession and its contribution to productivity growth. Journal of Infrastructure, Policy and Development 2: 11. [CrossRef]

Danileviciene, Irena, and Natalja Lace. 2017. The features of economic growth in the case of Latvia and Lithuania. Journal of Open Innovation: Technology, Market, and Complexity 3. [CrossRef]

Dhéret, Claire. 2014. Sharing the Same Vision-The Cornerstone of a New Industrial Policy for Europe; Discussion Paper. European Policy Centre, pp. 1-15. Available online: www.epc.eu (accessed on 1 May 2020).

Edquist, Harald Olof. 2011. Intangible Investment and the Swedish Manufacturing and Service Sector Paradox. The Review of Income and Wealth 57: 658-82. [CrossRef]

EU KLEMS. 2019. EU KLEMS Growth and Productivity Accounts Release 2019. Available online: https:/ / euklems.eu/ (accessed on 29 March 2021).

European Commission. 2009. European Industry in a Changing World. Updated Sectoral Overview 2009. COM 2009 204. Brussels: European Commission.

European Commission. 2010. An Integrated Industrial Policy for the Globalization Era. COM 2010 614. Brussels: European Commission.

European Commission. 2012. A Stronger European Industry for Growth and Economic Recovery. COM (2012) 582. Brussels: European Commission.

European Commission. 2013a. Towards Knowledge-Driven Reindustrialisation. European Competitiveness Report. Available online: http:/ / ec.europa.eu/enterprise/policies/industrial-competitiveness/competitiveness-analysis/european-competitivenessreport/ files / eu-2013-eur-comp-rep_en.pdf (accessed on 1 June 2020).

European Commission. 2013b. Investing in Intangibles: Economic Assets and Innovation Drivers for Growth. Flash Eurobarometer No. 369. Brussels: European Commission, Directorate-General for Enterprise and Industry.

European Commission. 2020. Una Nueva Estrategia Industrial Para una Europa Ecológica, Digital y Competitiva a Escala Mundial. Brussels: European Commission.

European Competitiveness Report. 2013. Towards Knowledge-Driven Reindustrialisation. Available online: https:/ / ec.europa.eu/ growth/content/european-competitiveness-report-2013-0_en (accessed on 1 June 2020).

European Round Table of Industrialists. 2017. European Competitiveness and Industry. Available online: http://ert-industrybenchmarking.eu/wp-content/uploads /2017/12/ERT-Stats_Benchmarking2017_4web_21122017hyperlinksgroupedBookmarks. pdf (accessed on 1 June 2020).

Falk, Martin. 2013. New Empirical Findings for International Investment in Intangible Assets. Working Paper. Work Package 305, MS61 Research Paper on the Determinants of Intangible Investment and Different Types of Innovation. Welfare, Wealth, Work for Europe. Available online: www.foreurope.eu (accessed on 1 July 2020).

Fukao, Kyoji, Tsutomu Miyagawa, Kentaro Mukai, Yukio Shinoda, and Konomi Tonogi. 2009. Intangible Investment in Japan: Measurement and Contribution to Economic Growth. Review of Income and Wealth 55: 717-36. [CrossRef]

Goodridge, Peter, Jonathan Haskel, and Gavin Wallis. 2013. Can Intangible Investment Explain the UK Productivity Puzzle? National Institute Economic Review 224: 48-58. [CrossRef]

Guellec, Dominique, and Bruno van Pottelsberghe De La Potterie. 2001. R\&D and Productivity Growth: Panel Data Analysis of 16 OECD Countries. OECD Economic Studies 33: 103-26.

Hao, Janet Xiaohui, Vlad Manole, and Bart Van Ark. 2009. Intangible Capital and Growth-An International Comparison. Commission, European Programme, Seventh Framework, 1-63. Available online: http:/ / citeseerx.ist.psu.edu/viewdoc/download?doi=10.1.1.454 $.3510 \&$ rep $=$ rep $1 \&$ type $=$ pdf (accessed on 1 June 2020).

Ilmakunnas, Pekka, and Hannu Piekkola. 2014. Intangible investment in people and productivity. Journal of Productivity Analysis 41: 443-56. [CrossRef]

Inklaar, Robert, Kirsten Jäger, Mary O’Mahony, and Bart van Ark. 2019. European productivity in the digital age: Evidence from EU KLEMS. In Measuring Economic Growth and Productivity: Foundations, KLEMS Production Models, and Extensions. Amsterdam: Elsevier Inc., pp. 75-94. [CrossRef]

Jalava, Jukka, Pirkko Aulin-Ahmavaara, and Aku Alanen. 2007. Intangible Capital in the Finnish Business Sector, 1975-2005; ETLA Discussion Papers. Helsinki: The Research Institute of the Finnish Economy (ETLA), vol. 1103, pp. 1-25. Available online: http:/ / www.econstor.eu/handle/10419/63632 (accessed on 1 April 2020).

Jona Lasinio, Cecilia, Massimiliano Iommi, and Stefano Manzocchi. 2011. Intangible Capital and Productivity Growth in European Countries. INNODRIVE Working Paper 10: 26. [CrossRef]

Kaus, Wolfhard, Viktor Slavtchev, and Markus Zimmermann. 2020. Intangible Capital and Productivity: Firm-Level Evidence from German Manufacturing. IWH Discussion Papers 1/2020. Halle: Halle Institute for Economic Research (IWH).

Kim, Keungoui, Ahmed Bounfour, Alberto Nonnis, and Altay Özaygen. 2021. Measuring ICT externalities and their contribution to productivity: A bilateral trade based approach. Telecommunications Policy 45. [CrossRef] 
Lev, Baruch, and Suresh Radhakrishnan. 2003. The Measurement of Firm-Specific Organization Capital. NBER Working Paper 9581. Cambridge: National Bureau of Economic Research.

Lev, Baruch, and Suresh Radhakrishnan. 2005. The Valuation of Organizational Capital. In Measuring Capital in the New Economy. Edited by Corrado Carol, Haltiwanger John and Sichel Daniel. Chicago: University Chicago Press, pp. 73-110.

Lichtenberg, Frank R. 1993. R\&D Investment and International Productivity Differences. In Economic Growth in the World Economy. Edited by Horst Siebert. Tubingen: J. C. B. Mohr, pp. 89-110.

Marrano, Mauro Giorgio, and Jonathan Haskel. 2006. How Much Does the UK Invest in Intangible Assets? Working Paper, 578, 28. London: Department of Economics Queen Mary. Available online: http://www.economics.qmul.ac.uk/papers/doc/wp578.pdf (accessed on 1 May 2020).

Marrano, Mauro Giorgio, Jonathan Haskel, and Gavin Walli. 2009. What happened to the Knowledge Economy? ICT, Intangible Investment, and Britain's Productivity Record revisited. Review of Income and Wealth 55: 686-716. [CrossRef]

Mas, Matilde, and Robert Stehrer. 2012. Industrial Productivity in Europe: Growth and Crisis. Edited by Mas Matilde and Stehrer Robert. Cheltenham and Northhampton: Edward Elgar.

Mc Morrow, Kieran, Werner Röger, and Alessandro Turrini. 2010. Determinants of TFP growth: A close look at industries driving the EU-US TFP gap. Structural Change and Economic Dynamics 21: 165-80. [CrossRef]

McGrattan, Ellen R. 2020. Intangible capital and measured productivity. Review of Economic Dynamics 37: 147-66. [CrossRef]

Miyagawa, Tsutomu, and Shoichi Hisa. 2013. Estimates of Intangible Investment by Industry and Productivity Growth in Japan. Japanese Economic Review 64: 42-72. [CrossRef]

Muntean, Tatiana. 2014. Intangible Assets and Their Contribution to Labour Productivity Growth in Ontario. International Productivity Monitor 27: 22-40.

Nakamura, Leonard. 1999. Intangibles: What put the new in the new economy? Business Review, 3-16. Available online: http: / / ideas.repec.org/a/fip/fedpbr/y1999ijulp3-16.html (accessed on 1 May 2020).

Nakamura, Leonard Isamu. 2001. What Is the US Gross Investment in Intangibles? (At Least) One Trillion Dollars a Year! Federal Reserve Bank of Philadelphia Working Paper 01-15. Philadelphia: Economic Research Division, Federal Reserve Bank of Philadelphia.

Niebel, Thomas, Mary O'Mahony, and Marianne Saam. 2017. The Contribution of Intangible Assets to Sectoral Productivity Growth in the EU. Review of Income and Wealth 63: 49-67. [CrossRef]

Novotna, Martina, and Tomáš Volek. 2018. Efficiency of production factors in the EU. DETUROPE-The Central European Journal of Regional Development and Tourism 10: 147-68.

O'Sullivan, Eoin, Antonio Andreoni, Carlos Lopez-Gomez, and Mike Gregory. 2013. What is new in the new industrial policy? A manufacturing systems perspective. Oxford Review of Economic Policy 29: 432-62. [CrossRef]

Park, Walter G. 1995. International R\&D Spillovers and OECD Economic Growth. Economic Inquiry 33: 571-91.

Park, HyunJee, and Sang Ok Choi. 2019. Digital innovation adoption and its economic impact focused on path analysis at national level. Journal of Open Innovation: Technology, Market, and Complexity 5: 56. [CrossRef]

Peiró-Palomino, Jesús. 2016. European regional convergence revisited: The role of intangible assets. Annals of Regional Science 57: 165-94. [CrossRef]

Petrakos, George, Dimitris Kallioras, and Ageliki Anagnostou. 2011. Regional Convergence and Growth in Europe: Understanding patterns and determinants. European Urban and Regional Studies 18: 375-91. [CrossRef]

Pianta, Mario. 2013. An Industrial Policy for Europe, Socialist Project, Global Research. Paper presented at 19th Conference on Alternative Economic Policy in Europe, London, UK, September 20-22.

Piekkola, Hannu. 2011. Intangible capital: The key to growth in Europe. Intereconomics 46: 222-28. [CrossRef]

Piekkola, Hannu. 2017. Broad-based intangibles as generators of growth in Europe. Economics of Innovation and Nerw Technology 27: 377-400. [CrossRef]

Piekkola, Hannu. 2020. Intangibles and innovation-labor-biased technical change. Journal of Intellectual Capital 21: 649-69. [CrossRef]

Pyka, Andreas, Kristina Bogner, and Sophie Urmetzer. 2019. Productivity Slowdown, Exhausted Opportunities and the Power of Human Ingenuity—Schumpeter Meets Georgescu-Roegen. Journal of Open Innovation Technology, Market and Complexity 5: 39. [CrossRef]

Roth, Felix. 2020. Revisiting intangible capital and labour productivity growth, 2000-2015: Accounting for the crisis and economic recovery in the EU. Journal of Intellectual Capital 21: 671-90. [CrossRef]

Roth, Felix, and Anna-Elisabeth Thum. 2011. Does Intangible Capital affect Economic Growth? Innodrive Working Paper 3: 1-47.

Roth, Felix, and Anna-Elisabeth Thum. 2013. Intangible capital and labor productivity growth: Panel evidence for the EU from 1998-2005. Review of Income and Wealth 59: 486-508. [CrossRef]

Sichel, Daniel. 2008. Intangible capital. In The New Palgrave Dictionary of Economics, 2nd ed. Edited by Steven Durlauf and Lawrence Blume. Palgrave Macmillan: Available online: http:/ / www.dictionaryofeconomics.com/article?id=pde2008_I000299 (accessed on 1 June 2020).

Stehrer, Robert, Alexandra Bykova, Kirsten Jäger, Oliver Reiter, and Monika Schwarzhappel. 2019. Industry level growth and productivity data with special focus on intangible assets. In Vienna Institute for International Economic Studies Statistical Report. WIIW Statistical Report No. 8. Vienna: Vienna Institute for International Economic Studies.

Strobel, Thomas. 2012. New evidence on the sources of EU countries productivity growth-industry growth differences from R\&D and competition. Empirica 39: 293-325. 
Timmer, Marcel, Ton van Moergastel, Edwin Stuivenwold, Gerard Ypma, Mary O'Mahony, and Mari Kangasniemi. 2007a. EUKLEMS Growth and Productivity Accounts, Version 1.0, Part I Methodology, March 2007. Available online: http:/ / www.euklems.net/ data/EUKLEMS_Growth_and_Productivity_Accounts_Part_I_(accessed on 1 July 2020).

Timmer, Marcel, Ton van Moergastel, Edwin Stuivenwold, Gerard Ypma, Mary O'Mahony, and Mari Kangasniemi. 2007b. EU KLEMS Growth and Productivity Accounts, Version 1.0. Part II Sources by Country, March 2007. Available online: http: / / www.euklems.net/data/EUKLEMS_Growth_and_Productivity (accessed on 1 July 2020).

Timmer, Marcel P., Robert Inklaar, Mary O'Mahony, and Bart Van Ark. 2010. Economic Growth in Europe. A Comparative Industry Perspective. Cambridge: Cambridge University Press, ISBN 978-0-521-19887-5.

Timmer, Marcel P., Robert Inklaar, Mary O'Mahony, and Bart Van Ark. 2011. Productivity and economic growth in Europe: A comparative industry perspective. International Productivity Monitor 21: 3-23.

Van Ark, Hubertus Bart. 2016. Europe's Productivity Slowdown Revisited: A comparative perspective to the United States. In Productivity Puzzles Across Europe. Edited by Askenazy Philippe, Bellmann Lutz, Bryson Alex and Galbis Eva Moreno. Oxford: Oxford University Press, pp. 26-48.

Van Ark, Bart, and Kirsten Jäger. 2017. Recent Trends in Europe's Output and Productivity Growth Performance at the Sector Level, 2002-2015. International Productivity Monitor 33: 8-23.

Van Ark, Bart, and Mary O'Mahony. 2016. Productivity Growth in Europe before and since the 2008/2009 economic and financial crisis. In The World Economy: Growth Stagnation. Edited by Jorgenson Dale W., Fukao Kyoji and Timmer Marcel P. Cambridge: Cambridge University Press, pp. 111-52.

Van Ark, Bart, Janet X. Hao, Carol Corrado, and Charles Hulten. 2009. Measuring intangible capital and its contribution to economic growth in Europe. European Investment Bank EIB Papers 14: 62-93.

van Rooijen-Horsten, Myriam, Dirk Van den Bergen, and Murat Tanriseven. 2008. Intangible Capital in The Netherlands: A Benchmark. Discussion Paper (08001), 22. Statistics Netherlands. Vorburg/Heerlen. Available online: http://www.cbs.nl/NR/rdonlyres/ DE0167DE-BFB8-4EA1-A55C-FF0A5AFCBA32/0/200801x10pub.pdf (accessed on 1 July 2020).

Yallwe, Alem Hagos, and Antonino Buscemi. 2014. An Era of Intangible Assets. Journal of Applied Finance E Banking 4: 17-26. 